\title{
New species of the ostracod genus Neosinocythere Huang (1985) from the Indo-West Pacific Region
}

\author{
QUANHONG ZHAO \\ Department of Marine Geology \\ Tongji University \\ Shanghai \\ China
}

\author{
ROBIN WHATLEY \\ Institute of Earth Studies \\ University College of Wales \\ Aberystwyth, Dyfed SY23 2DB \\ U.K.
}

\begin{abstract}
Four new species of the ostracod genus Neosinocythere are described from the Indo-West Pacific region: $N$. indica, N. macropunctata, N. micropunctata and $N$. indowestpacifica. The diagnoses of Neosinocythere and the subfamily Sinocytherinae Huang are emended. J. Micropalaeontol., 12 (1): 1-8, August 1993.
\end{abstract}

\section{INTRODUCTION}

Huang (1985) established Neosinocythere on the single species Sinocythere reticulata Chen, 1982 and placed it, together with two other genera (Sinocythere Hou, 1982 and Spinileberis Hanai, 1961), in the new family Sinocytheridae. Neosinocythere was once thought to be monospecific and endemic to China, where it is found commonly in Miocene to Recent shallow marine and coastal brackish deposits of eastern China (Guan et al., 1978, Hou et al., 1982; Gou et al., 1983; Huang, 1985; Wang \& Zhao, 1985; Zhao, 1985; Zhao \& Wang, 1985; and others). In the course of our joint study on the Cainozoic Ostracoda of the Indo-West Pacific, we have collected new material of Neosinocythere from Indonesia, Malaysia, the Malacca Straits, India and Réunion, which markedly expands its geographical distribution, showing it to be an important element of the Indowestpacific fauna. The type specimens of the new species and the figured specimens of $N$. elongata are deposited in the Department of Zoology, The Natural History Museum, London.

\section{SYSTEMATIC DESCRIPTIONS}

Order Podocopida Müller, 1894

Suborder Podocopina Sars, 1866

Superfamily Cytheracea Baird, 1850

Family Trachyleberididae Sylvester-Bradley, 1948

Subfamily Sinocytherinae Huang, 1985

Original diagnosis. Valve rectangular to trapezoid in lateral view. Surface reticulate or with nodes and ridges. A tubercle between two anterodorsal sulci.

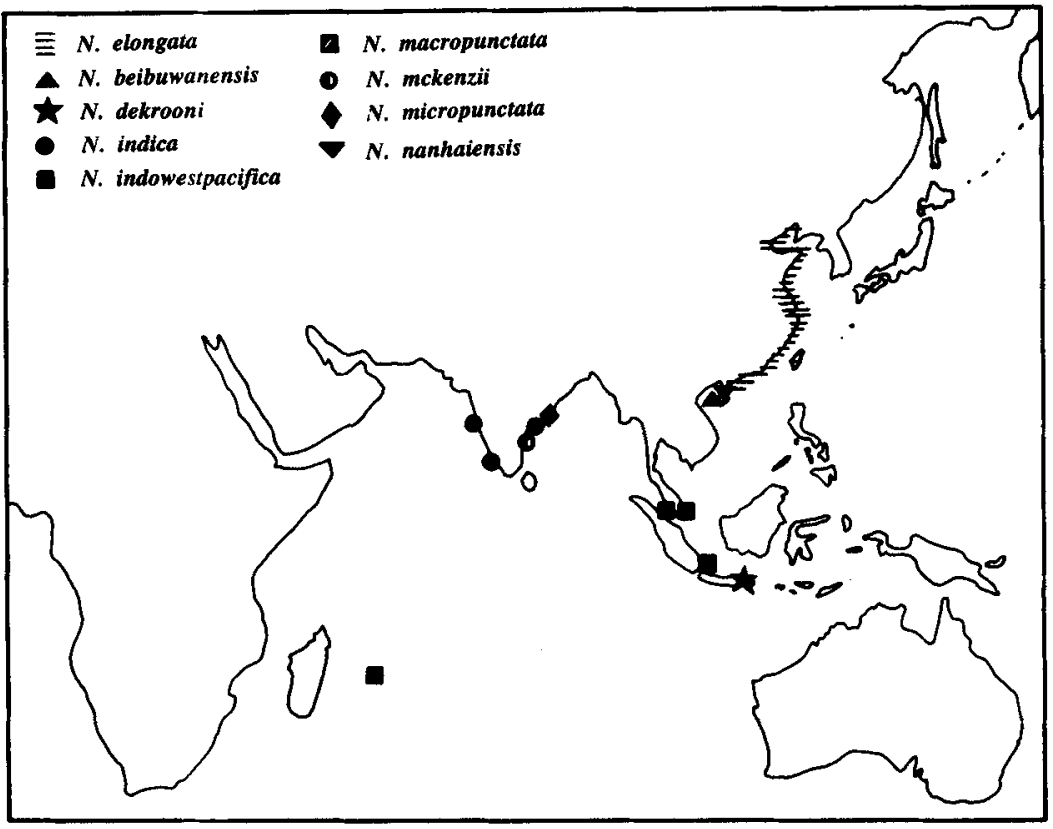

Fig. 1 Geographical distribution of known species of Neosinocythere in the Indo-west Pacific Region.

Emended diagnosis. Small to medium, subrectangular to subtriangular in lateral view with or without caudal process posteroventrally. Surface reticulate, costate, tuberculate or punctate; always with an ocular rib, a prominent subcentral tubercle and its surrounding sulcus. Sexual dimorphism distinct. Hinge modified holamphidont; posterior tooth of $\mathrm{RV}$ reniform and slightly denticulate with a shallow ventral concavity, anterior tooth smooth or denticulate; in LV posterior socket always with an anti-slip toothlet ventrally. Inner lamella wide, avestibulate or with very small anterior vestibule, marginal pore canals few in number. Adductor 
muscle scars small in size, consisting of 4 close-packed scars; frontal scar single, oval or heart-shaped.

Remarks. Members of the Sinocytherinae are similar to those of the Trachyleberidinae Sylvester-Bradley in hinge and adductor muscle scars but differ in having a prominent subcentral tubercle with a surrounding sulcus, and with posterior anti-slip toothlet of the LV. The posterior anti-slip toothlet of the LV, is similar to "aurilid" genera of the Hemicytheridae Puri, but the latter have different frontal and adductor muscle scars. The subfamily bears considerable resemblance to the Orionininae (Hemicytheridae), and Neosinocythere externally is very similar to Caudites Coryell \& Fields. These resemblances are superficial; the soft parts and musculature of the two groups are quite distinct. Five genera are included in the subfamily: Cathaycythere Whatley \& Zhao, 1986, Neosinocythere Huang, 1985, Paracathaycythere Whatley \& Zhao (M.S. in press), Sinocythere Hou, 1982 and Spinileberis Hanai, 1961.

Distribution. Miocene to Recent, eastern and southern Asia, Indian Ocean, West Pacific.

\section{Genus Neosinocythere Huang, 1985}

Type species. Orionina elongata $\mathrm{Hu}, 1976$

Original description. Valve trapezoid to triangular in lateral view, thick-shelled. Posterior end triangular, surface of valve with two sulci anterodorsally, reticulation, nodes and depression. Hinge of left valve consists of anterior and posterior sockets and middle crenulate bar. Marginal zone moderately broad, with some straight, simple and scattered pore-canals. Vestibule absent.

Emended description. Caudal process posteroventrally always present in females, sometimes present in males. Anterior and posterior cardinal angles distinct, and particularly in LV of females where it is swollen to form a prominent hinge-ear. Surface reticulate or punctate; an ocular rib extends from anterior cardinal angle to midanterior, commonly with 3 nodes posteriorly and one node anteroventrally, one thin anterior marginal rim and 4 thin longitudinal (dorsal, median, subventral and ventral) ribs. Median rib extends diagonally from posterodorsal node and is interrupted by the sub-central tubercle. Carapace compressed anteriorly, posteroventrally and posterodorsally. Eye tubercle weakly present. LV overhangs RV dorsally and overlaps it along posterodorsal margin. Hinge modified holamphidont, in RV anterior tooth smooth, tablet-shaped and perpendicular in side view to dorsal margin, posterior tooth short, slightly lobate and curved with a shallow ventral concavity which serves to receive the anti-slip toothlet of the LV; in LV anterior socket always enclosed by a crescentic ventral bar which extends anteriorly from the conical anteromedian tooth, posteromedian bar denticulate. Inner lamella wide, especially anteriorly and posteroventral; avestibulate; marginal pore canals few, widely spaced and mostly simple. Adductor muscle scars a vertical row of 4 small closely adjacent scars; both frontal and mandibular scars are single and ovate.

Remarks. Huang (1985) erected Neosinocythere with Sinocythere reticulata Chen, 1982 as type species. S. reticulata is identified by the present authors as the junior synonym of Atopocythere superba Guan, 1978 and Orionina elongata $\mathrm{Hu}$, 1976. One of the notable features of this genus is the strong sexual dimorphism; the female is not only shorter and higher than the male but also always has a posteroventral caudal process, which is absent in the male of some species, such as $N$. indica, $N$. indowestpacifica and $N$. macropunctata. Sinocythere Hou, 1982, the genus most similar to Neosinocythere, lacks the triangular caudal process in both sexes and is the feature on which the two genera are separated. Neosinocythere differs from Spinileberis Hanai, 1961 in that the sexual dimorphism in the latter is much weaker and its posteroventral inner lamella is narrow and the posterior nodes are usually not developed.

To date the following 8 species are included in

Neosinocythere:

Cythereis dekrooni Kingma, 1948

Orionina elongata $\mathrm{Hu}, 1976$

(= Atopocythere superba Guan 1978 andSinocythere reticulata

Chen, in Hou et al., 1982)

Palmella mckenzii Annapurna \& Sarma, 1985

Puriana? nanhaiensis Chen, in Hou et al., 1981

Neosinocythere indica sp. nov.

Neosinocythere indowestpacifica sp. nov.

Neosinocythere macropunctata sp.nov.

Neosinocythere micropunctata sp. nov.

Sulcostocythere? beibuwanensis Chen, in Hou et al., 1981 probably belongs to the genus.

Distribution. Miocene to Recent; China, southeastern Asia, Indian Ocean, West Pacific; shallow marine to coastal brackish water. The geographical distribution of the nine species is shown in Fig. 1. The species are mostly warm-

\section{Explanation of Plate 1}

$\mathrm{F}=$ female, $\mathrm{M}=$ male

Figs. 1-7 Neosinocythere elongata (Hu), 1976. Fig.1. F, ARV (1991.330), external lateral view x80; Fig. 2. M, ARV (1991.331), external lateral view x80; Fig. 3. M, AC (1991.332), left lateral view x80; Figs 4,5. M, ALV (1991.334), internal lateral view, 4. x80; 5 . Adductor muscle scars, x240. 6. M ARV (1991.335), internal lateral view x80; 7. M AC (1991.333), dorsal view x80.

Figs 8,9 Neosinocythere dekrooni (Kingma), 1948 x95 F, AC (T402), right and left external view .

Figs 10-17 Neosinocythere indica sp.nov. x65. Fig.10. Holotype F, AC (1991.336), right lateral view; Fig.11. Paratype F, ALV (1991.337), external lateral view; Fig.12. Paratype F, AC (1991.338), dorsal view; Fig.13. Paratype M, AC (1991.340), right lateral view; Fig.14. Paratype M, AC (1991.339), left lateral view; Fig.15. Paratype M, AC (1991.341), dorsal view; Fig.16. Paratype M, ALV (1991.342), internal lateral view; Fig.17. Paratype M, ARV (1991.343), internal lateral view.

Fig.18 Neosinocythere indowestpacifica sp.nov. x95. Paratype F, ALV (1991.345), external view. 


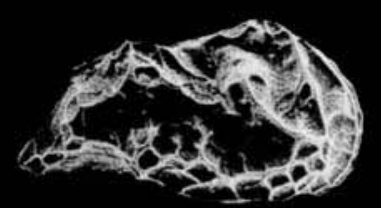

1

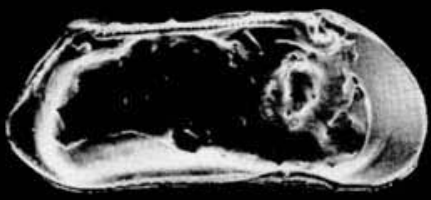

4

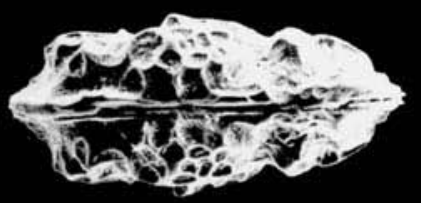

7

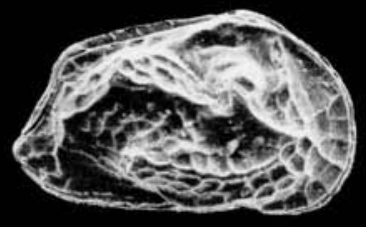

10

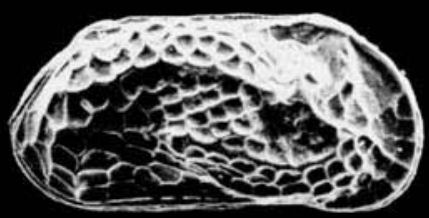

13

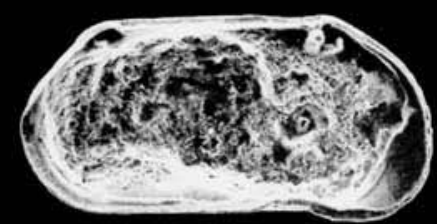

16

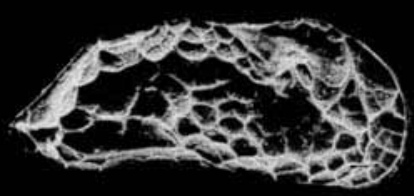

2

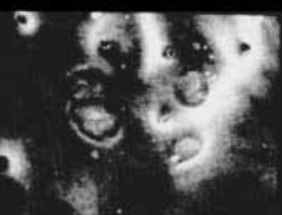

5

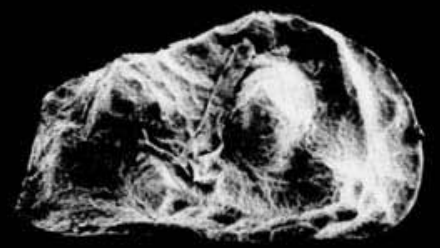

8

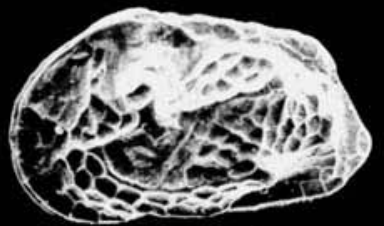

11
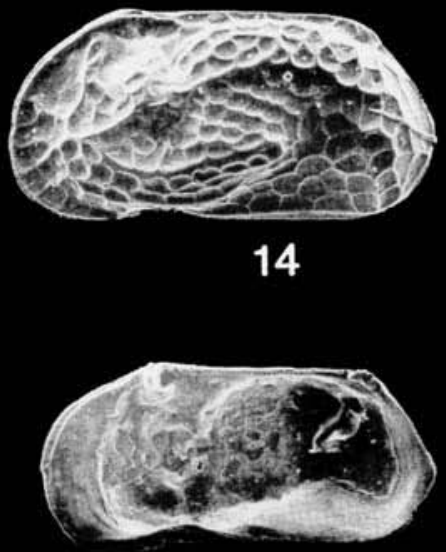

17

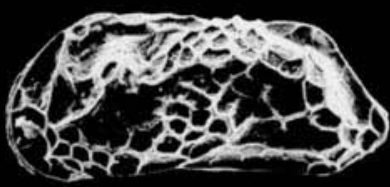

3

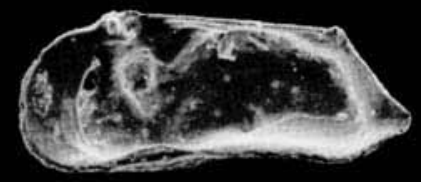

6

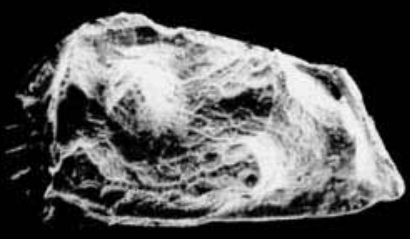

9

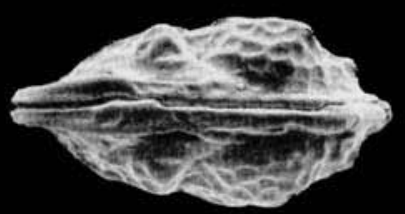

12
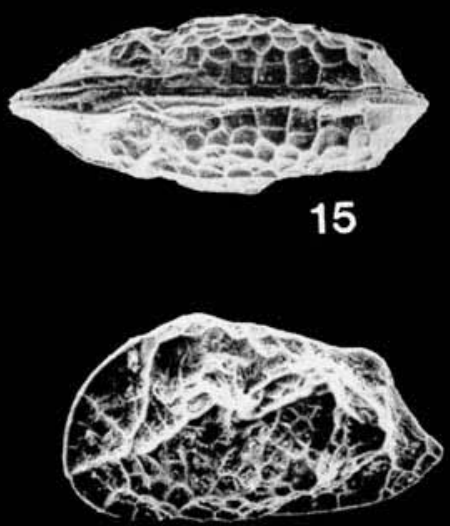

18 
water inhabitants restricted to the tropics. The single exception is $N$. elongata, which is eurythermal with a wide latitudinal distribution from the tropics to the temperate zone along the coast of China.

\section{Neosinocythere elongata $(\mathrm{Hu}), 1976$}

(Pl. 1, figs 1-7)

1976 Orionina elongata $\mathrm{Hu}, \mathrm{p} .38,39$, text-figs $10-\mathrm{C}, \mathrm{D}$ (not 10 A,B), Pl.3, figs 20,21 (not 4,12).

1978 Atopocythere superba Guan, p.289, Pl.75, fig.13.

1982 Sinocythere reticulata Chen, p.243, 244, P1.87, figs 1-9. 1983 Sinocythere reticulata Chen, Gou et al., p.107, Pl.21, figs 38-45.

1985 Neosinocythere reticulata (Chen), Huang, p.49, Pl.1, figs 14,15 .

1988 Sinocythere reticulata Chen, Zen et al., p.279, Pl.70, figs

$16,17$.

Diagnosis. Both sexes with prominent drawn out caudal process. Ornamentation of polygonal reticulation with finely punctate sola, bifid ocular rib anteriorly, an anterior marginal rib with very narrow frill, 4 thin longitudinal ribs, nodes at the posterodorsal, posteroventral and midposterior areas.

Dimensions (mm)

$\begin{array}{lcccc} & & \text { length } & \text { height } & \text { width } \\ \text { RV } & 1991.330 & 0.45 & 0.25 & \\ \text { RV } & 1991.331 & 0.53 & 0.23 & \\ \text { Car. } & 1991.332 & 0.53 & 0.23 & 0.23 \\ \text { Car. } & 1881,333 & 0.52 & 0.23 & 0.23 \\ \text { LV } & 1991.334 & 0.56 & 0.25 & \\ \text { RV } & 1991.335 & 0.53 & 0.23 & \end{array}$

Remarks. Orionina elongata Hu 1976 was based on Pliocene material from Taiwan. In the original paper two carapaces were designated as the holotype (text-figs $10-\mathrm{C}, \mathrm{D}, \mathrm{Pl} .3$, figs 20,21 ) and paratype (shown by text-figs $10-\mathrm{A}, \mathrm{B}, \mathrm{Pl} .3$, figs 4,12 ). The paratype differs in ornament from the holotype, especially in having a long and prominent ocular rib extending from the anterior cardinal angle diagonally to the anteroventral margin; it probably belongs to Cathaycythere Whatley \& Zhao. The holotype is a male.

Distribution. Miocene to Recent of East China; the modern representatives occur along the entire coast of China between Lat. $20^{\circ}$ and $41^{\circ} \mathrm{N}$, commonly in estuaries, tidal and subtidal zones with water depth less than $20 \mathrm{~m}$, rarely in deeper shelf down to a depth of some $70 \mathrm{~m}$ (Wang \& Zhao, 1985; Zhao et al., 1985). Living carapaces have been reported from the estuary of the Yangze River from a salinity less than $25 \%$ o (Zhao, 1985).

\section{Neosinocythere dekrooni (Kingma), 1948 \\ (Pl. 1, figs 8,9)}

1948 Cythereis dekrooni Kingma, p.79,80, pl.9, figs 15a,b. 1980 Cythereis dekrooni Kingma, p.200.

1988 Sinocythere dekrooni (Kingma), Zhao \& Whatley, p.243,244, pl.4, figs 9-12.

Lectotype. An adult female carapace (T402), deposited in the Department of Stratigraphy and Paleontology, Institute of Earth Science, University of Utrecht, the Netherlands.

Diagnosis. Subquadrate in lateral view, with well rounded anterior margin, straight but slightly declined dorsal margin, truncated posterior margin and triangular caudal process posteroventrally. Ventral and subventral ribs distinct, the latter extending between anteroventral and posteroventral nodes; dorsal and median ribs not developed. Reticulation very feeble and finely punctate.

Type Locality. Upper Kaliberg Bed (Upper Pliocene), Sangiran, E. Java, Indonesia.

Dimensions. (mm)

Lectotype

$\begin{array}{llll}\text { Car. (T402) } & 0.43 & 0.23 & 0.23\end{array}$

Remarks. Zhao \& Whatley (1989) re-examined the type specimens of Cythereis dekrooni and designated a lectotype and paralectotypes. Only the female of this species is known.

Distribution. Pliocene to Pleistocene, E. Java, Indonesia.

\section{Neosinocythere indica sp.nov.} (Pl.1, figs 10-17)

1981 Genus A Jain, p.108, Pl.2, fig.7.

Derivation of name. From its distribution along the eastern coast of India.

Diagnosis. Dimorphism prominent, females with triangular caudal process posteroventrally which is absent in males. Surface reticulation with smooth sola.

Holotype. An adult female carapace, 1991.

Type locality. Eastern coast of India.

Dimensions (mm)

\section{Explanation of Plate 2}

Figs 1-3 Neosinocythere indowestpacifica sp.nov. x95. Fig.1. Holotype F, AC (1991.344), right lateral view; Fig.2. Paratype F, AC (1991.346), dorsal view; Fig.3. Paratype F, ALV (1991.347), internal lateral view.

Figs 4-10 Neosinocythere macropunctata sp.nov. x95. Figs 4,5. Paratype F, AC (1991.350), right lateral and dorsal view; Fig.6 Paratype F, AC (1991.349), left lateral view; Fig.7 Holotype M, AC (1991.348), left lateral view; Fig.8 Paratype M, JAC (1991.353), dorsal view; Fig.9 Paratype F, JAC (1991.351), left lateral view; Fig.10 Paratype M, JAC (1991.352), right lateral view.

Figs 11-18 Neosinocythere micropunctata sp.nov. x110. Fig.11. Paratype M, AC (1991.359), dorsal view; Fig.12. Paratype M, AC (1991.356), left lateral view; Fig.13. Holotype F, AC (1991.354), right lateral view; Fig.14. Paratype F, AC (1991.358), dorsal view; Fig.15. Paratype F, ALV (1991.357), external lateral view; Fig.16. Paratype M, AC (1991.355), right lateral view; Fig.17 Paratype F, ALV (1991.360), internal lateral view Fig. 18. Paratype F, ARV (1991.361), internal lateral view. 


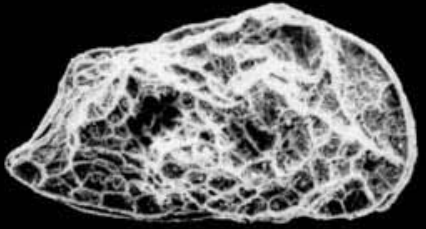

1

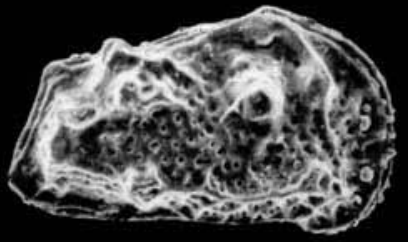

4

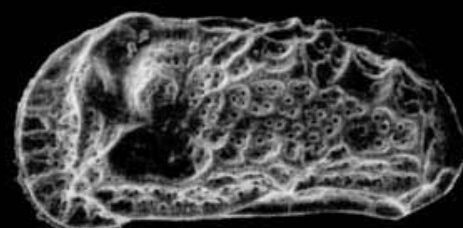

7

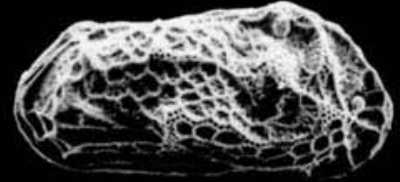

10

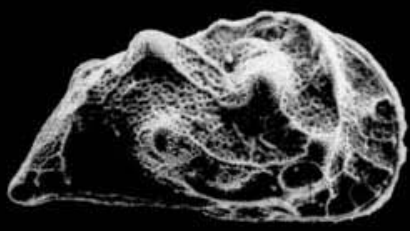

13

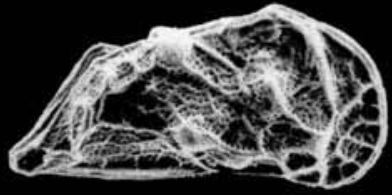

16
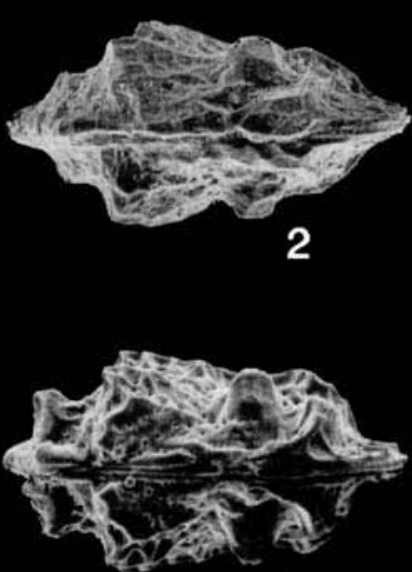

5

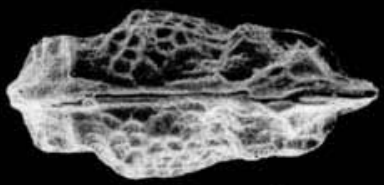

8

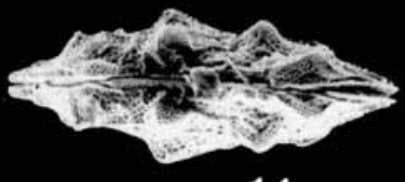

11

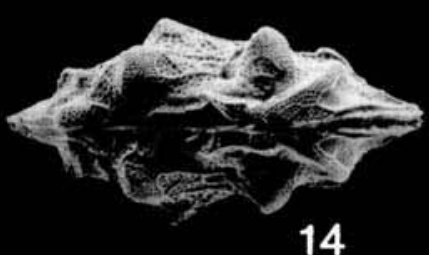

14

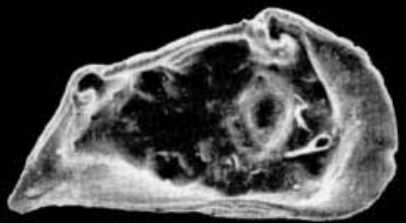

17
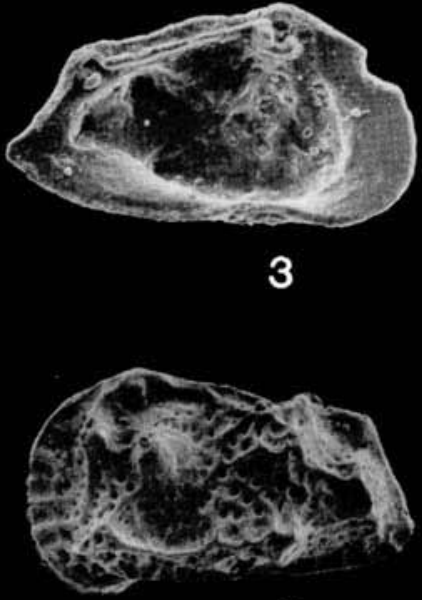

6

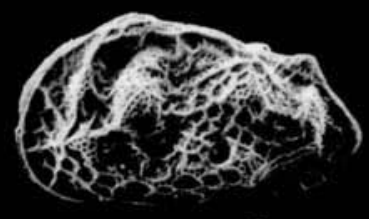

9
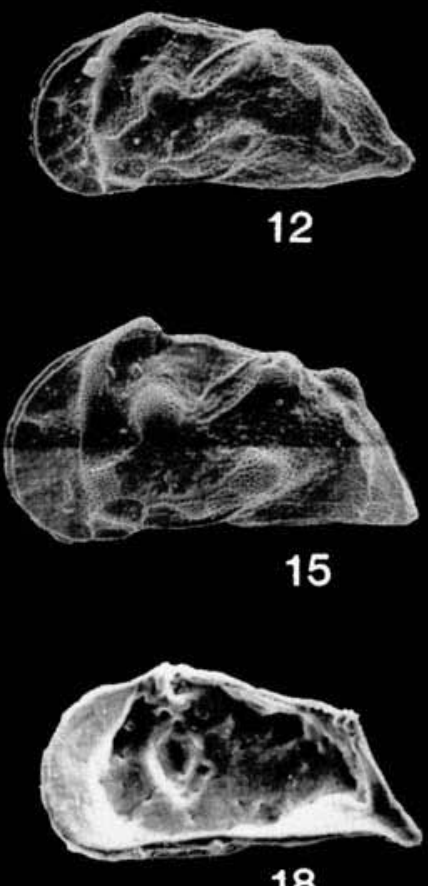


$\begin{array}{lccc} & \text { length } & \text { height } & \text { width } \\ \text { Holotype Car. 1991.336 } & 0.54 & 0.33 & 0.29 \\ \text { Paratype LV. 1991.337 } & 0.59 & 0.36 & \\ \text { Paratype Car. 1991.338 } & 0.57 & 0.34 & 0.29 \\ \text { Paratype Car. 1991.339 } & 0.66 & 0.32 & 0.28 \\ \text { Paratype Car. 1991.340 } & 0.65 & 0.32 & 0.29 \\ \text { Paratype Car. 1991.341 } & 0.66 & 0.33 & 0.28 \\ \text { Paratype LV. 1991.342 } & 0.66 & 0.32 & \\ \text { Paratype RV. 1991.343 } & 0.62 & 0.34 & \end{array}$

Material. 26 living carapaces (17 females and 9 males).

Description. Males subrectancular and females nearly quadrate in lateral view. In males dorsal and ventral margins almost parallel; upper part of posterior margin truncated, lower part narrowly rounded. In females dorsal margin declines posteriorly, and the lower part of the posterior margin protrudes to form a triangular caudal process. Anterior and posterior cardinal angles distinct, particularly in the LV of females. Surface reticulation consists of polygonal fossae and smooth sola, superimposed with 4 thin longitudinal ribs: dorsal rib very feeble, especially in males; median rib not reaching anterior margin; subventral rib ending at posteroventral node posteriorly; ventral rib short and overhung. A thin rib extends along anterior margin, ornamented with very narrow frill. Carapace, especially in females, compressed along anterior, posteroventral, posterodorsal and dorsal margins. The male has weaker posterior nodes and lacks a caudal process. Inner lammela wide anteriorly and posteroventrally, and inner margin markedly protruded inwards in posteroventral area; 7 anterior and 2 posterior marginal pore canals.

Remarks. The new species is the largest of the genus. It differs from $N$. elongata $\mathrm{Hu}$ in that the male lacks the posteroventral caudal process, and the sola of the reticulation are smooth.

Distribution. Recent of western and eastern coasts of India.

\section{Neosinocythere indowestpacifica sp.nov.}

(Pl.1, Fig.18; Pl.2, figs 1-3)

1987 ?Sinocythere superba (Guan), Whatley and Zhao, p.341, pl.2, fig. 27 .

1989 ?Caudites sp. Whatley \& Keeler, p.71, pl.2, figs 14,15,17.

Derivation of name. After its distribution in the Indian and west Pacific regions.

Diagnosis. A reticulate species characterised by its prominent median rib sloping downwards from posterodorsal node and reaching to anterior margin.

Holotype. An adult female carapace, 1991.

Type locality. Medium sandy intertidal zone, Harbour of Saint Pierre, Réunion.

Dimensions (mm)

Holotype Car. 1991 344

$\begin{array}{ccc}\text { length } & \text { height } & \text { width } \\ 0.45 & 0.24 & 0.23 \\ 0.41 & 0.24 & \\ 0.43 & 0.25 & 0.24 \\ 0.43 & 0.24 & \end{array}$

Paratype LV. 1991.345

Paratype Car. 1991.346

Paratype LV. 1991.347

0.43

0.24

Material. 18 female carapaces and 1LV, 1 male carapace; all dead.
Description. Small, thick-shelled. Sexual dimorphism distinct; males subrectangular in lateral view with blunt posterior end whereas females subtriangular to subquadrate with pointed caudal process. Ventral margin shallowly concave antero-medianly where obscured by ventral rib; anterior margin rounded; upper part of posterior margin truncated and slightly concave, lower part in females triangularly protruded and in male narrowly rounded. Reticulation well developed, covering entire surface; sola finely punctate. Subcentral tubercle, surrounding sulcus, posterior 3 nodes, ocular rib, anterior rib and 4 longitudinal ribs are all distinct, the diagonal median rib being the most conspicuous reaching the anterior margin. Internal characters similar to those of $N$. indica.

Remarks. This species is distinguished by its long median rib reaching the anterior margin. The material from the type locality consists entirely of females, the only male carapace recorded (Whatley \& Zhao, 1987, pl.2 fig.27) coming from the bottom sediments of the Malacca Straits (Whatley \& Zhao, 1987, pl.2 Fig.27).

Distribution. Recent, intertidal zone of Saint-Pierre Harbour, Réunion; reef lagoon of Palau Pari Island off western Java; and the Malacca Straits from a depth of $38 \mathrm{~m}$; all dead.

\section{Neosinocythere macropunctata sp.nov.}

(Pl.2, figs 4-10)

1989 Sinocythere superba (Guan), Shao \& Whatley, p.187.

Derivation of name. With reference to the surface ornament of coarse punctae.

Diagnosis. Strong sexual dimorphism, posteroventral margin rounded in males, triangularly protruded in females. Surface reticulation irregular in shape and size, and sola coarsely punctate.

Holotype. An adult male carapace, 1991. 348.

Type locality. Station 11, approximately lat. $1^{\circ} 56^{\prime} \mathrm{N}$, long. $104^{\circ} 05^{\prime} \mathrm{S}$, estuary of the Sedili River, southeastern coast of the Malay Peninsula, some $8 \mathrm{~km}$ upstream from river mouth with bottom water salinity $8 \%$ o.

Measurements. (mm)

$\begin{array}{llccc}\text { Holotype } & \text { Car. 1991.348 } & \text { length } & \text { height } & \text { width } \\ \text { Paratype } & \text { Car. 1991.349 } & 0.49 & 0.23 & 0.22 \\ \text { Paratype } & \text { Car. 1991.350 } & 0.43 & 0.23 & 0.23 \\ \text { Paratype } & \text { JCar. 1991.351 } & 0.37 & 0.23 & 0.24 \\ \text { Paratype } & \text { JCar. 1991.352 } & 0.42 & 0.21 & 0.18 \\ \text { Paratype } & \text { JCar. 1991.353 } & 0.40 & 0.19 & 0.18 \\ \end{array}$

Material. 14 living carapaces ( 7 females and 7 males), and 2 dead specimens.

Description. The male is subrectangular in lateral view with a well rounded anterior margin, straight and parallel dorsal and ventral margins, truncated posterodorsal and narrowly rounded posteroventral margins; the female dorsal margin declines posteriorly, and the postroventral margin is triangularly protruded. Surface reticulation irregular in shape and size, tending to be smaller towards 
the centre of the valve; sola coarsely punctate. A thin rib extends along the anterior margin and has 8-9 minute marginal denticles. Some 9 radial ribs are present along the anterior margin. Carapace compressed along anterior, posterovantral and posterodorsal margins.

Remarks. $N$. macropunctata is very similar in its prominent dimorphism to $N$. indica, but differs in having irregular reticulation, coarsely punctate sola and radial ribs along the anterior margin.. N. elongata is similar, but differs in the male having a more distinct caudal process and finely punctate sola. $N$. macropunctata differs from $N$. dekrooni in having stronger reticulation and coarser punctae.

Distribution. Recent, estuary of the Sedili River, southeast Malay Peninsula; living specimens were found in the section between the river mouth and some $8 \mathrm{~km}$ upstream where bottom salinity ranged from $34 \%$ o to $8 \%$.

\section{Neosinocythere micropunctata sp.nov.}

(Pl.2, figs 11-18)

Derivation of name. After the finely punctate surface.

Diagnosis. Small, subtriangular in lateral view with acuminate posteroventral caudal process in both males and females. Surface densely and finely punctate, especially on raised relief (nodes and ribs) where punctae are much denser and smaller. Reticulation and longitudinal ribs weakly developed.

Holotype. An adult female carapace, 1991.

Type locality.

Dimensions. (mm)

$\begin{array}{lcccc}\text { Holotype } & \text { Car. 1991.354 } & 0 ., 38 & 0.21 & 0.18 \\ \text { Paratype } & \text { Car. 1991.355 } & 0.36 & 0.18 & 0.15 \\ \text { Paratype } & \text { Car. 1991.356 } & 0.36 & 0.17 & 0.13 \\ \text { Paratype } & \text { LV. 1991.357 } & 0.38 & 0.20 & \\ \text { Paratype } & \text { Car. 1991.358 } & 0.40 & 0.22 & 0.19 \\ \text { Paratype } & \text { Car. 1991.359 } & 0.36 & 0.18 & 0.16 \\ \text { Paratype } & \text { LV. 1991.360 } & 0.37 & 0.20 & \\ \text { Paratype } & \text { RV. 1991.361 } & 0.37 & 0.20 & \end{array}$

Description. Both anterior and posterior cardinal angles of female left valves protrude to form distinct hinge-ears. Ocular rib thick, extending from anterior cardinal angle downwards tomid-anterior. Four other nodes situated respectively at anteroventral, posterodorsal, mid-posterior and posteroventral areas, of which the posterodorsal and posteroventral nodes are most prominent and rounded in shape. Anterior marginal rib thin and ornamented with very narrow frill. Of the four longitudinal ribs, the dorsal two ribs are very weak and the ventral tworibs distinct and convex ventrally. Reticulation very feeble, absent on most areas of surface butwith fine and dense punctae, especially on raised nodes and ribs where the punctae are more minute and denser. Internal characters as for $N$. indica.

Remarks. This is readily distinguished from other species. Distribution. Recent, eastern coast of India.

\section{ACKNOWLEGEMENTS}

We wish to thank Drs G.W. Hughes and C. Harris of
Robertson Research, UK, Sukandarrumidi of Gadjah Mada University, Indonesia and Dr I.K. McMillan, Miss P. Turner of Aston University, Dr K. Watson and Dr M.S. Mannikeri of Karnatak University, India for kindly providing the samples respectively from Malaysia, the Malacca Straits, Indonesia, India and Réunion. The study was supported by the British Council under the ALCS.

\section{Manuscript received: September 1991 \\ Manuscript accepted: January 1993}

\section{REFERENCES}

Annapurna, C. and Rama Sarma, D.V. 1985. Occurrence of a podocopan ostracod Palmella mckenzii sp.nov. in the marginal water bodies, eastcoast of India. Journ. Geol. Soc. India, 26, 141-144.

Gou, Y., Chen, T. et al. 1981. Ostracoda. In: Hou et al., The Atlas of Tertiary Paleontology of North Continental Shelf of South China Sea. Guangdong Sci. \& Tech. Press, 138-187.

Gou, Y., Zheng, S. and Huang, B. 1983. Pliocene ostracode fauna of Leizhou Peninsula and northern Hainan Island, Guangdong Province. Paleont. Sinica, n.ser., B.18, 1-134.

Guan, S., Sun Q. et al. 1978. Ostracoda In: Paleontological Atlas of Central and South China. Geol. Publ. House, Beijing, 4, 115-324

Hou, Y., Chen, T. et al. 1982. Cretaceous-Quaternary Ostracod Fauna from Jiangsu. Geol. Publ. House, Beijing, 298pp.

$\mathrm{Hu}, \mathrm{C} .1976$. Studies on the Pliocene ostracodes from the Cholan Formation, Miaoli District, Taiwan. Proc. Geol. Soc. China (Taiwan), 19, 25-51.

Huang, B. 1985. Ostracoda from the column samples under surface deposit on the bottom of North Bohai Sea. Journ. Oceanogr. Huanghai $\mathcal{E}$ Bohai Seas, 3(4), 42-52.

Jain, S.P. 1981. Recent Ostracoda from southwest Kerala coast, India. Bull. Ind. Geol. Assoc., 14(2), 107-120.

Kingma, A.J. 1948. Contributions to the knowledge of the Young Cenozoic Ostracoda from the Malayan region. Utrecht, Kemink Ptrs., 1-118.

Wang, P. and Zhao, Q. 1985. Ostracod distribution in bottom sediments of the east China Sea. In: Wang, P. et al., Marine Micropaleontology of China. China Ocean Press, 70-92

Whatley, R. \& Keeler, N. 1989. Ostracodes actuels de l'île de la Réunion (sud-ouest de l'Océan Indien). Revue de Micropal., 32(1), 63-84.

Whatley, R. \& Zhao, Q. 1978. On Sinocythere sinensis Hou. Stereo-Atlas of Ostracod Shell, 14(2), 5-8.

Whatley, R. \& Zhao, Q. 1987. On Cathaycythere reticulata gen. et. sp.nov. Stereo-Atlas of Ostracod Shell, 14(3), 1-4.

Whatley, R. \& Zhao, Q. (in press). Paracathaycythere costaereticulata gen. et. sp.nov. Stereo-Atlas of Ostracod Shell.

Zhao, Q. 1985. A study on distribution of Recent coastal ostracod faunas of the East China and Yellow Seas. Acta Oceanogr. Sinica, 7(2), 194-204.

Zhao, Q. \& Wang, P. 1988. Distribution of modern Ostracoda in the shelf seas off China. In: Hanai, T., Ikeya, N. and Ishizaki, K. (eds). Evolutionary Biology of Ostracoda, 805-821.

Zhao, Q., Wang, P. \& Zhang, Q. 1985. Ostracoda in bottom sediments of the South China Sea off Guangdong Province, China: Their taxonomy and distribution. In: Wang, P. et al., Marine Micropaleontology of China. China Ocean Press, 196-217.

Zhao, Q. \& Whatley, R. 1989. Recent podocopid Ostracoda of the Sedili River and Jason Bay, southeastern Malay Peninsula. Micropal., 35(2), 168-187.

Zhao, Q. \& Whatley, R. 1989. A taxonomic review of the new species of Ostracoda described by J.T. Kingma (1948) from the late Cainozoic of Indonesia. Acta Micropal. Sinica, 6(3), 229-246. 